\title{
Venlafaxine Inhibits the Apoptosis of SHSY-5Y Cells Through Active Wnt/ $\beta$-Catenin Signaling Pathway
}

\author{
Ruijie Geng' \\ Haibin Li ${ }^{\prime}{ }^{\prime}$ \\ Hao Wang ${ }^{2}$ \\ Chenyu Ye' \\ Yemeng $\mathrm{Mao}^{3}$ \\ Xiao Huang $\mathbb{I D}^{1,4}$
}

'Department of Psychological Medicine, Zhongshan Hospital, Fudan University, Shanghai, People's Republic of China;

${ }^{2}$ Teaching Center of Experimental

Medicine, Shanghai Medical College,

Fudan University, Shanghai, People's

Republic of China; ${ }^{3}$ Department of

Pharmacy, Shanghai Mental Health

Center, Shanghai Jiaotong University School of Medicine, Shanghai, People's Republic of China; ${ }^{4}$ Department of Psychological Medicine, Xiamen Branch, Zhongshan Hospital, Fudan University,

Xiamen, Fujian, People's Republic of China

Correspondence: Xiao Huang Department of Psychological Medicine, Xiamen Branch, Zhongshan Hospital, Fudan University, Xiamen, 361015, Fujian,

People's Republic of China

Tel +86-0592-3501990

Email huang.xiao@zs-hospital.sh.cn

Yemeng Mao

Department of Pharmacy, Shanghai

Mental Health Center, Shanghai Jiaotong

University School of Medicine, 600 South

Wanping Road, Shanghai, 200030,

People's Republic of China

Tel +86-2I-64387250

Email mao_yemeng@I63.com
Objective: This study aimed to explore the mechanism of venlafaxine in regulating the apoptosis of SHSY-5Y cells induced by hypoxia.

Methods: The CoCl2-induced neuronal hypoxia model was established based on SHSY-5Y cells. The morphology and related protein expression of SHSY-5Y cells were detected by qPCR, ELISA and Western blot.

Results: Under the condition of hypoxia-induced by $\mathrm{CoCl} 2$, the expression of HIF-1 $\alpha$ in SHSY-5Y cells was up-regulated and the expression of $\beta$-catenin was down-regulated. After adding siRNA targeting HIF-1 $\alpha$ to the culture cell system, down-regulation of $\beta$-catenin expression in SHSY-5Y cells was restored. This confirmed the existence of the "hypoxia-HIF $-1 \alpha$-Wnt/ $\beta$-catenin-depression" axis. Further studies have shown that venlafaxine can alleviate neuronal apoptosis induced by hypoxia by upregulating the $\mathrm{Wnt} / \beta$-catenin signaling pathway.

Conclusion: Venlafaxine regulates apoptosis induced by hypoxia through the Wnt/ $\beta$-catenin signaling pathway, which provides a new theoretical basis for the treatment of depression.

Keywords: venlafaxine, Wnt/ $\beta$-catenin, SHSY-5Y cells, apoptosis

\section{Introduction}

Depression is the fourth largest disease in the world, affecting 350 million people worldwide (2015, WHO), with high rates of disability and mortality. ${ }^{1}$ Depression causes serious mental problems and cognitive impairment to patients and even threatens their lives, as well as a heavy burden on patients' families and society. ${ }^{2}$ It is worth noting that depression usually begins in young people. ${ }^{3}$ Therefore, the elaboration of the molecular level of depression and the corresponding early intervention is very important for individuals, families, and even the whole society. ${ }^{4-9}$

Wnt/ $\beta$-catenin pathway abnormalities are related to the occurrence and development of a variety of diseases (eg, tumors, Alzheimer's disease, metabolic diseases, etc.). ${ }^{10-15}$ Down-regulation of the Wnt/ $\beta$-catenin signaling pathway has been confirmed as an important mechanism of depression. Besides, depression symptoms caused by long-term hypoxia have been widely concerned. Therefore, it is necessary to explore the molecular mechanism between hypoxia and depression. ${ }^{16} \mathrm{HIF}$ $1 \alpha$ is the most important cytokine expressed by cells in the hypoxic environment, $^{17,18}$ which has been shown to inhibit the Wnt/ $\beta$-catenin signaling pathway in the development of skeletal muscle. 
Venlafaxine is a dual antidepressant for serotonin and norepinephrine reuptake inhibitors. ${ }^{19-22}$ Venlafaxine can selectively block the 5-hydroxytryptamine transporter and norepinephrine transporter, and it has a very low affinity for cholinergic, histaminergic, and adrenergic receptors. ${ }^{23}$ Its pharmacological properties are unique with no obvious adverse reactions caused by tricyclic antidepressants. Venlafaxine is the first-line treatment drug recommended by disorder prevention guidelines for depressive disorder and general anxiety in China.

SHSY-5Y cells are human bone marrow cells derived from adult human neuroblastomas. Their chromosome number is 47 and the phenotype is Philadelphia chromosome-positive. SHSY-5Y cells are often used in neurological and psychiatric research due to their neuronal characteristics. In this study, SHSY-5Y cells were used to test the hypothesis of "hypoxia-HIF- $1 \alpha$-Wnt/ $\beta$-catenindepression" and then to explore the role of venlafaxine in regulating the apoptosis of SHSY-5Y cells caused by hypoxia through the $\mathrm{Wnt} / \beta$-catenin signaling pathway.

\section{Methods}

\section{Cell Culture}

We purchased human dopaminergic neuroblastoma cell line, SHSY5Y cells, from the Chinese Type Culture Collection. SHSY-5Y cells were cultured in DMEM medium supplemented with $10 \%$ fetal bovine serum and penicillin/streptomycin, maintained at $5 \% \mathrm{CO} 2$ and $37^{\circ} \mathrm{C}$. The culture medium was updated twice a week. The experiments were performed using $0.5 \times 106$ cells per well under 12-well plates or otherwise specified conditions. In the SHSY-5Y cell culture system, cobalt chloride (CoCl2) was used to create anoxic environment and treated with venlafaxine. The experiments were divided into blank control group, $\mathrm{CoCl} 2$ treatment group, venlafaxine and $\mathrm{CoCl} 2$ treatment group, and test cells. We detect changes in all aspects of the cell.

\section{siRNA Transfection}

According to literature reports, HIF- $1 \alpha$ siRNA and $\beta$ catenin siRNA were designed using online software. SHSY-5Y cells were transfected at a density of about $60 \%$ to $70 \%$ as instructed by the Lipofectamine 3000 transfection reagent. The cells were cultured for 48 hours after transfection. ${ }^{24}$

\section{Detection of the Expression of HIF-IA} and $\beta$-Catenin

The tissues were homogenized with $0.5 \mathrm{~mL}$ ice-cold lysis buffer. The composition of ice-cold lysate is $20 \mathrm{mM}$ Tris$\mathrm{HCl}, 1 \mathrm{mM}$ DTT, $1 \mathrm{mM}$ EDTA, $5 \mathrm{mM} \mathrm{MgCl} 2,2 \mathrm{mM}$ sodium orthovanadate, $20 \mu \mathrm{g} / \mathrm{mL}$ aprotinin and $1 \mathrm{mM}$ PMSF, pH 7.5. Centrifuge the homogenate at $10,000 \times \mathrm{g}$ at $4^{\circ} \mathrm{C}$ for 20 minutes, and then remove the supernatant. With bovine serum albumin as the standard, the protein concentration was determined using the bicinchoninic acid method. After boiling the sample for 5 minutes ( 30 $\mu \mathrm{g} / \mathrm{mL}$ protein per lane), it was separated by $15 \%$ SDSPAGE and transferred to a nitrocellulose membrane (EMD Millipore, Billerica, MA, USA). Subsequently, the nitrocellulose membranes were blocked with $5 \%$ bovine serum albumin for $1.5 \mathrm{~h}$ at room temperature, and incubated with anti-PPAR $\alpha$ rabbit antibody (1:1000; catalog number ab8934) at $4{ }^{\circ} \mathrm{C}$ for $12 \mathrm{~h}$. After that, the membrane was washed three times with TBS-Tween 20 buffer and incubated with HRP-conjugated goat antirabbit IgG H\&L secondary antibody (1:200; catalog number ab6721) for 1 hour at room temperature. GDV for specific frequency bands was measured using Quantity One version 4.62 software (Bio-Rad Laboratories, Inc., Hercules, CA, USA).

\section{Quantitative Real-Time PCR}

First-strand cDNA was obtained using the Reverse Transcription System (Promega), Oligo(dT) and Stemloop Reverse Transcription primer for mRNA and miRNA. Quantitative real-time PCR (qPCR) was performed on LightCycler 480 (Roche, Basel, Switzerland) using SYBR Premier Dimer Eraser ${ }^{\mathrm{TM}}$ (TaKaRa, Dalian, China). Data were analyzed using the relative quantitative $(244 \mathrm{Ct})$ method.

\section{Statistical Analysis}

Statistical analysis was performed using GraphPad Prism 4 and SPSS 13.0 software. The results are expressed as mean $\pm \mathrm{SD}$. Analysis of variance (ANOVA) was used for the three sets of analysis and the Newman-Keuls test was followed. Student's $t$-test was used to compare the two groups. Kruskal-Wallis and Mann-Whitney $U$-tests were used to analyze the data of non-normal distributions. 


\section{Results}

\section{Effect of Hypoxia Environment Caused by Cobalt Chloride on SHSY-5Y Cells}

In the hypoxia environment induced by $\mathrm{CoCl} 2$, the number of apoptotic and necrotic cells was significantly increased (Figure 1A and B) and SHSY-5Y cellular morphology was shrinking (Figure 1C and D). The expression of HIF $-1 \alpha$ was up-regulated in the SHSY-5Y cell (Figure 1E). The hypoxic environment induced by cobalt chloride significantly downregulated the expression of $\beta$-catenin (Figure $1 \mathrm{~F}$ and $\mathrm{G}$ ) $(P<0.05)$.

\section{The Association of HIF-I $\alpha$ with Wnt/ $\beta$ - Catenin Signaling Pathway}

The siRNA targeting HIF-1 $\alpha$ was added to the cultured cell system. Cobalt chloride-induced down-regulation of $\beta$ catenin expression in SHSY-5Y cells was restored (Figure 2).

\section{Relationship Between Venlafaxine and Apoptosis of SHSY-5Y Cells Induced by Cobalt Chloride}

As shown in Figure (Figure 3A-C), venlafaxine can alleviate the apoptosis of SHSY-5Y cells induced by cobalt chloride.

\section{Relationship Between Venlafaxine and Proteins Related to Wnt- $\beta$-Catenin Signaling Pathway in SHSY-5Y Cells}

Detection of Wnt/ $\beta$-catenin signaling pathway-associated proteins in apoptotic SHSY-5Y cells induced by $\mathrm{CoCl}$, which were treated with Venlafaxine. The results (Figure 4) showed that partial Wnt- $\beta$-catenin signaling pathwayrelated proteins' levels of transcribed and translated were significantly increased $(P<0.01)$.

The Correlation of Venlafaxine and Wnt/ $\beta$-Catenin Signaling Pathway of Neuronal Apoptosis Induced by Hypoxia

Designing siRNA targeting $\beta$-catenin for further experiments.

The results showed that venlafaxine could alleviate apoptosis caused by cobalt chloride, but the addition of siRNA targeting $\beta$-catenin further aggravated apoptosis (Figure 5).

\section{Discussions}

Depression is one of the major refractory diseases in the field of psychosis and has a significant impact on human health. $^{25}$ Therefore, it is very important to explore the etiology and molecular mechanism of depression,
A

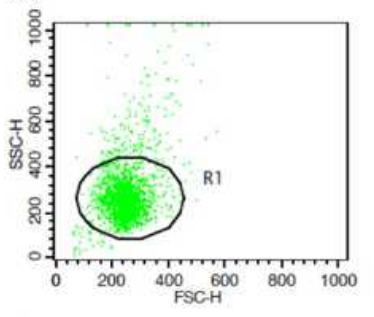

C

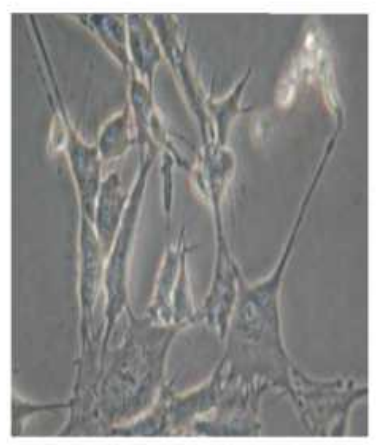

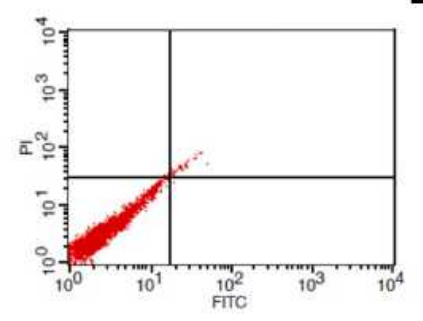

D

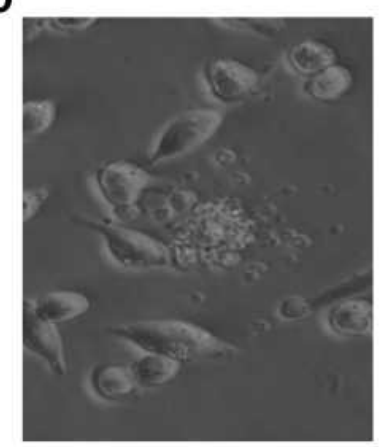

B
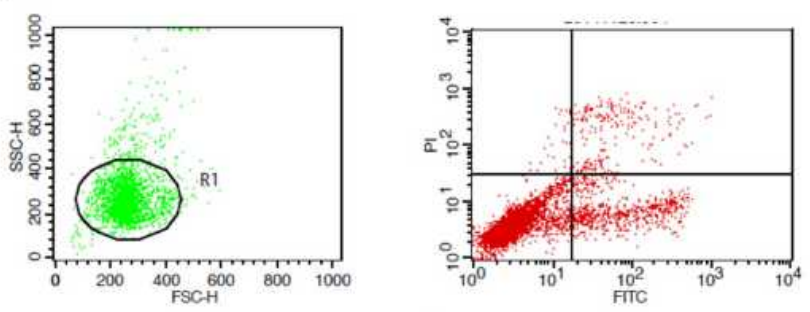

G

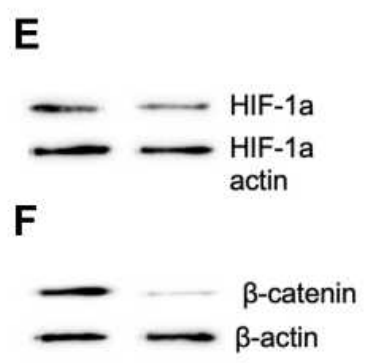

Figure I Effect of hypoxic environment caused by cobalt chloride on SHSY-5Y cells. (A) The number of apoptotic and necrotic cells in normal culture condition; (B) the number of apoptotic and necrotic cells in cobalt chloride-induced hypoxic environment; (C) SHSY-5Y cellular morphology in normal culture condition; (D) SHSY-5Y cellular morphology in cobalt chloride-induced hypoxic environment; (E) the expression of HIF $-I \alpha$ in SHSY-5Y cell; (F) cobalt chloride-induced hypoxia inhibited $\beta$-catenin expression detected by Western blot; $(\mathbf{G})$ the hypoxia-induced by cobalt chloride inhibited the expression of $\beta$-catenin at the transcriptional level detected by qPCR $(P<0.05)$. 


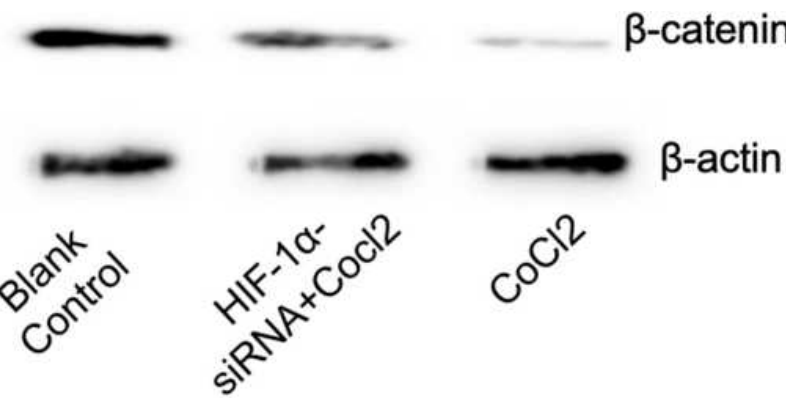

Figure 2 Effect of HIF-I $\alpha$ siRNA on the expression of $\beta$-catenin in SHSY-5Y cells induced by cobalt chloride.

including epidemiological etiology and signaling molecular pathways.

The Wnt/ $\beta$-catenin pathway is an active signaling pathway in the body, which can maintain neuronal and mental homeostasis through BDNF. In the resting state, the phosphorylation of $\beta$-catenin is completed by a destructive complex that is dominated by glycogen synthase kinase $3 \beta$ (GSK-3 $\beta$ ), axin, and adenomatous polyposis coli (APC) ${ }^{26,27}$ Then it can be recognized by $\beta$-TrCP containing the F-BOX domain and specifically binds to the site of phosphorylation of $\beta$-catenin, which in turn leads to the ubiquitination of $\beta$-catenin. In this way, the latter is eventually degraded by ubiquitin. It should be noted that most of the phosphorylated sites can promote the degradation of $\beta$-catenin, while the phosphorylation of certain amino acid sites (such as Ser45 and Thr41) increases the stability of $\beta$-catenin. In the $\mathrm{Wnt} / \beta$-catenin signaling pathway, the Wnt protein firstly binds to the co-receptors formed by the Frizzled (Fz) family receptor and the low-density lipoprotein receptor-associated protein 5 or 6 (LRP5/6), thereby forming ternary protein complex on the surface of cells.
A

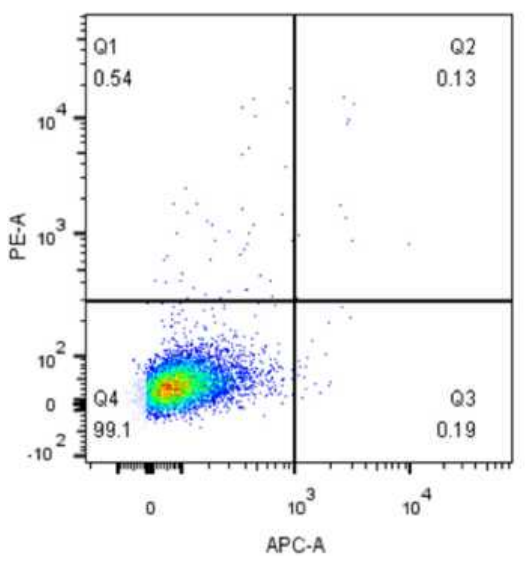

B

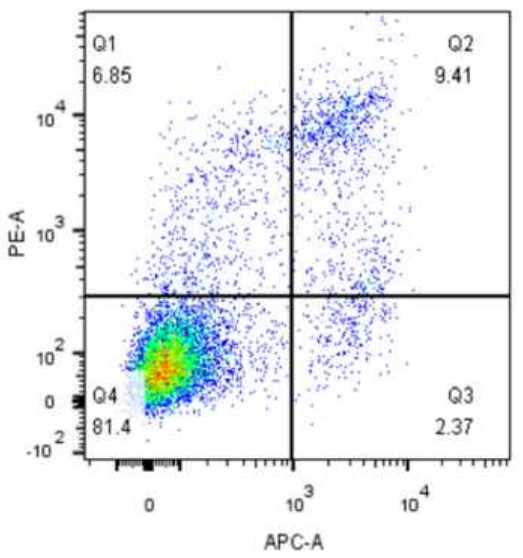

C

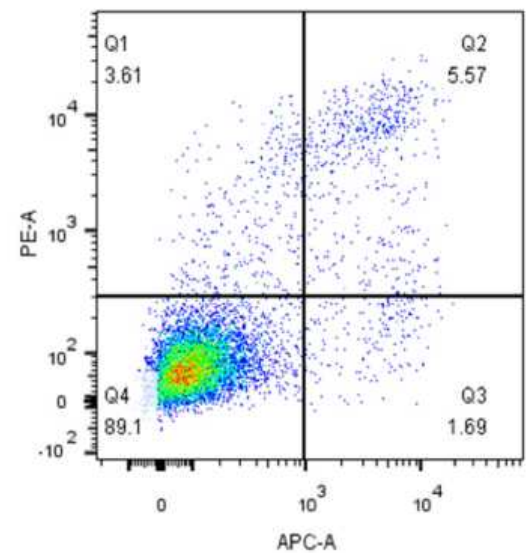

Figure 3 Effect of venlafaxine on apoptosis of SHSY-5Y cells induced by cobalt chloride. (A) Control group cells; (B) cobalt chloride-induced apoptosis of SHSY-5Y cells; (C) venlafaxine alleviated the apoptosis of SHSY-5Y cells induced by cobalt chloride.

A

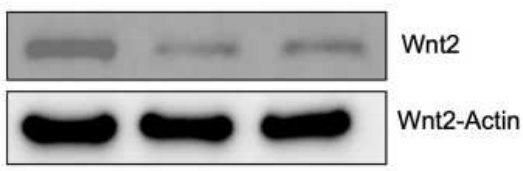

Venlafaxine $\mathrm{CoCl}_{2}$ Blank Control $+\mathrm{CoCl}_{2}$

B

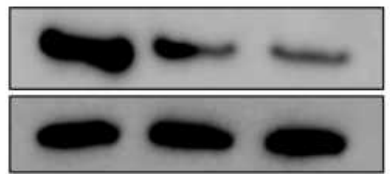

Blank Control Venlafaxine $\mathrm{CoCl}_{2}$ $+\mathrm{CoCl}_{2}$
C

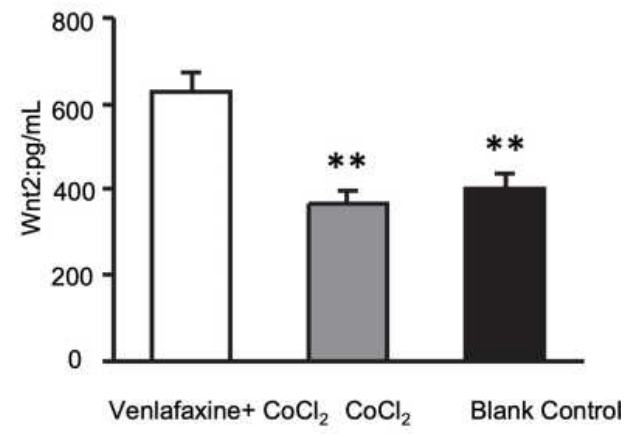

Figure 4 Venlafaxine up-regulated Wnt- $\beta$-catenin signaling pathway associated proteins in SHSY-5Y Cell. (A) The expression of Wnt2 in three groups; (B) the expression of $\beta$-catenin in three groups; $(\mathbf{C})$ the expression of $W n t 2$ at the transcriptional level detected by qPCR $(* * P<0.01)$. 
A

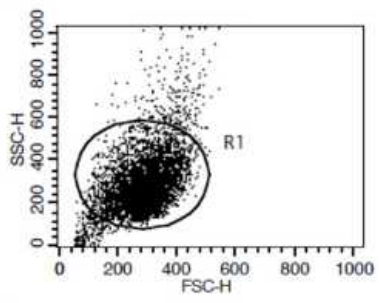

C

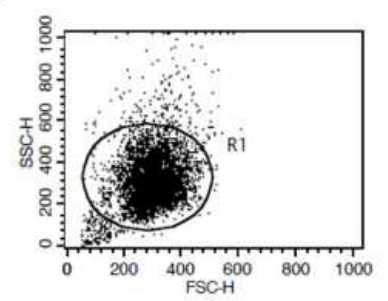

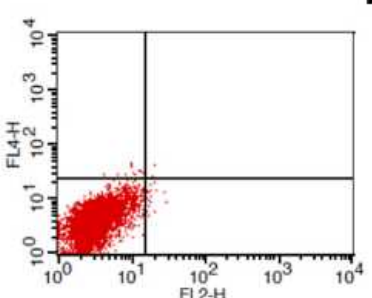

B

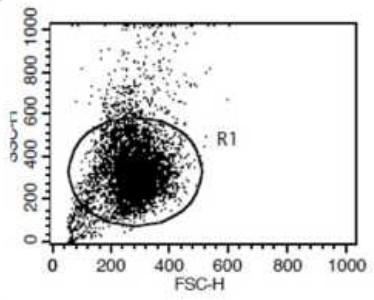

D
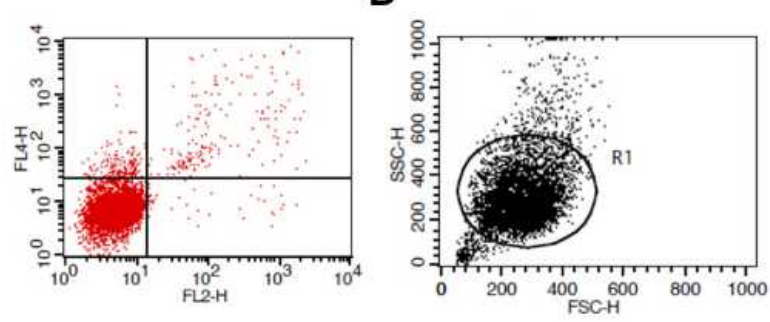
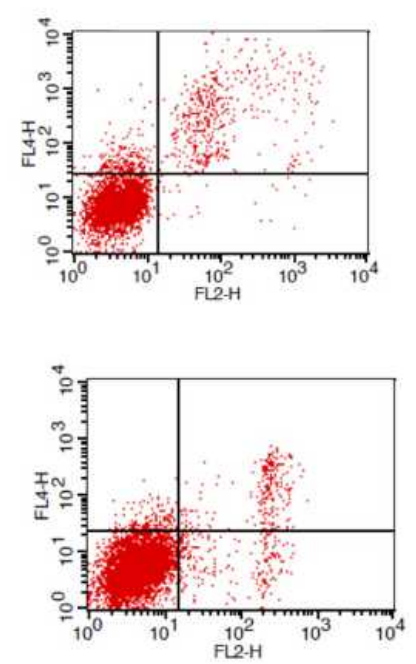

Figure 5 Effect of $\beta$-catenin siRNA on apoptosis of SHSY-5Y cells induced by cobalt chloride alleviated by venlafaxine. (A) Control group cells; (B) cobalt chloride-induced apoptosis of SHSY-5Y cells; (C) venlafaxine relieved the apoptosis of SHSY-5Y cells induced by cobalt chloride; (D) $\beta$-catenin siRNA inhibited the effect of relieved by venlafaxine on apoptosis.

This ternary complex then reacts with intracellular folded protein Dishevell (Dvl) to mediate dissociation of the $\beta$ catenin complex (GSK-3[beta], Axin and APC). $\beta$ catenin dissociated from GSK-3 $\beta$ is activated by dephosphorylation and translocated into the nucleus, which mediates the expression of the target gene (such as BDNF) after binding to the LEF1/TCF transcription factor in the nucleus. ${ }^{28}$

Venlafaxine, as a phenylethylamine derivative, is currently the most common antidepressant drug. ${ }^{29}$ Various studies have confirmed that venlafaxine can upregulate a variety of $\mathrm{Wnt} / \beta$-catenin signaling pathway-related proteins and activate the entire $\mathrm{Wnt} / \mathrm{B}$-catenin signaling pathway. ${ }^{30-32}$ SHSY-5Y cells, a cell line derived from neuroblastoma, can also be infected with various viral vectors while exhibiting neuronal cell characteristics.

In this study, we constructed the model of hypoxiainduced by cobalt chloride on the basis of SHSY-5Y cells. Under the condition of hypoxia-induced by cobalt chloride, we found that the expression of HIF-1 $\alpha$ was up-regulated in SHSY-5Y cells and the expression of $\beta$-catenin was downregulated. When siRNA targeting HIF-1 $\alpha$ was added to the cultured cell system, the down-regulation of $\beta$-catenin expression in SHSY-5Y cells was restored. This confirmed the "hypoxia-HIF- $1 \alpha$-Wnt/ $\beta$-catenin-depression" axis. ${ }^{33-36}$ Further studies have shown that venlafaxine could alleviate neuronal apoptosis induced by hypoxia by upregulating the Wnt/ $\beta$-catenin signaling pathway. ${ }^{37-39}$
From the results of this study, we can obtain some clinical benefits. Such as Detecting HIF-1 $\alpha$ to early diagnose/predict the incidence of depression, finding key nodes in the hypoxia-HIF- $1 \alpha-\mathrm{Wnt} / \beta$-catenin-depressive axis, and screening for effective small molecule targeting agonists or antagonists is expected to effectively treat depression.

\section{Conclusions}

In this study, we established models of neuron hypoxia induced by $\mathrm{CoCl} 2$ based on SHSY-5Y cells. The results showed that venlafaxine can alleviate neuronal apoptosis induced by hypoxia through upregulating $\mathrm{Wnt} / \beta$-catenin signaling pathway, which provides a new theoretical basis for the treatment of depression.

\section{Abbreviations}

$\mathrm{CoCl} 2$, cobalt chloride; ELISA, Enzyme linked immunosorbent assay; qPCR, quantitative real-time PCR; ANOVA, Analysis of variance; GSK-3 $\beta$, glycogen synthase kinase 3; APC, adenomatous polyposis coli; LRP5/6, lipoprotein receptor-associated protein 5 or 6; DMEM, Dulbecco's Modified Eagle Medium; SD, Standard deviation; BDNF, Brain-derived neurotrophic factor; DTT, Dithiothreitol; $\mathrm{HCl}$, hydrogen chloride; EDTA, Ethylene Diamine Tetraacetic Acid; $\mathrm{MgCl}$, Magnesium chloride; PMSF, Phenylmethylsulfonyl fluoride; SDS-PAGE, polyacrylamide gel electrophoresis. 


\section{Author Contributions}

All authors made a significant contribution to the conception, study design, execution, and acquisition of data, analysis and interpretation. They participated in drafting, revising or critically reviewing the article. They gave final approval of the version to be published and agreed upon the journal to which the article has been submitted and agreed to be accountable for all aspects of the work.

\section{Funding}

This work was supported by grants from the Construction of Public Health System in Shanghai (Mental and Mental Health) (No.GWV-10.2-XD26) and the Open Project of National Key Laboratory of Medical Immunology (NKMI2020K15).

\section{Disclosure}

The authors disclose no conflict.

\section{References}

1. Kang HJ, Kim SY, Bae KY, et al. Comorbidity of depression with physical disorders: research and clinical implications. Chonnam Med J. 2015;51(1):8-18. doi:10.4068/cmj.2015.51.1.8

2. Kent L, Van Doorn G, Klein B. Time dilation and acceleration in depression. Acta Psychol (Amst). 2019;194:77-86. doi:10.1016/j. actpsy.2019.02.003

3. Kertz SJ, Petersen DR, Stevens KT. Cognitive and attentional vulnerability to depression in youth: a review. Clin Psychol Rev. 2019;71:63-77. doi:10.1016/j.cpr.2019.01.004

4. Frieder A, Fersh M, Hainline R, Deligiannidis KM. Pharmacotherapy of postpartum depression: current approaches and novel drug development. CNS Drugs. 2019;33(3):265-282. doi:10.1007/ s40263-019-00605-7

5. Chi X, Wang S, Baloch Z, et al. Research progress on classical traditional Chinese medicine formula lily bulb and rehmannia decoction in the treatment of depression. Biomed Pharmacother. 2019;112:108616. doi:10.1016/j.biopha.2019.108616

6. Willi J, Ehlert U. Assessment of perimenopausal depression: a review. $J$ Affect Disord. 2019;249:216-222. doi:10.1016/j. jad.2019.02.029

7. Butler T, Harvey P, Cardozo L, et al. Epilepsy, depression, and growth hormone. Epilepsy Behav. 2019;94:297-300. doi:10.1016/j. yebeh.2019.01.022

8. Dinan TG, Cryan JF. Gut microbes and depression: still waiting for godot. Brain Behav Immun. 2019;79:1-2. doi:10.1016/j. bbi.2019.02.007

9. Wang JQ, Mao L. The ERK pathway: molecular mechanisms and treatment of depression. Mol Neurobiol. 2019;56(9):6197-6205. doi:10.1007/s12035-019-1524-3

10. Xu C, Tian G, Jiang C, et al. NPTX2 promotes colorectal cancer growth and liver metastasis by the activation of the canonical Wnt/ beta-catenin pathway via FZD6. Cell Death Dis. 2019;10(3):217. doi:10.1038/s41419-019-1467-7

11. Santos HBP, Medeiros HCM, Mafra RP, Miguel MCC, Galvão HC, de Souza LB. Regulation of Wnt/ $\beta$-catenin pathway may be related to Reg $\gamma$ in benign epithelial odontogenic lesions. Oral Surg Oral Med Oral Pathol Oral Radiol. 2019;128(1):43-51. doi:10.1016/j. oooo.2018.12.019
12. Turcios L, Chacon E, Garcia C, et al. Autophagic flux modulation by Wnt/beta-catenin pathway inhibition in hepatocellular carcinoma. PLoS One. 2019;14(2):e0212538. doi:10.1371/journal.pone.0212538

13. Luke JJ, Bao R, Sweis RF, Spranger S, Gajewski TF. WNT/betacatenin pathway activation correlates with immune exclusion across human cancers. Clin Cancer Res. 2019;25(10):3074-3083. doi:10.1158/1078-0432.CCR-18-1942

14. Javadinia SA, Shahidsales S, Fanipakdel A, et al. Therapeutic potential of targeting the Wnt/beta-catenin pathway in the treatment of pancreatic cancer. J Cell Biochem. 2018. doi:10.1002/jcb.27835

15. Yonezawa $\mathrm{H}$, Ogawa $\mathrm{M}$, Katayama S, et al. Clotrimazole inhibits the Wnt/beta-catenin pathway by activating two eIF2alpha kinases: the heme-regulated translational inhibitor and the double-stranded RNA-induced protein kinase. Biochem Biophys Res Commun. 2018;506(1):183-188. doi:10.1016/j.bbrc.2018.10.053

16. Kushwah N, Jain V, Deep S, Prasad D, Singh SB, Khan N. Neuroprotective role of intermittent hypobaric hypoxia in unpredictable chronic mild stress induced depression in rats. PLoS One. 2016;11(2):e0149309. doi:10.1371/journal.pone.0149309

17. Li HL, Zaghloul N, Ahmed I, et al. Caffeine inhibits hypoxia-induced nuclear accumulation in HIF-1alpha and promotes neonatal neuronal survival. Exp Neurol. 2019;317:66-77. doi:10.1016/j. expneurol.2019.01.014

18. Tsai HL, Miao ZF, Chen YT, et al. miR-148a inhibits early relapsed colorectal cancers and the secretion of VEGF by indirectly targeting HIF-1alpha under non-hypoxia/hypoxia conditions. $J$ Cell Mol Med. 2019;23(5):3572-3582. doi:10.1111/jcmm. 14257

19. Khan S, Sivananthan M, Bacon O. Serotonin sensitivity and withdrawal with low-dose venlafaxine. Prim Care Companion CNS Disord. 2019;21(1). doi:10.4088/PCC.18102334

20. Yuan R, Yuan F, Ren D, et al. HTR1A and HTR2A variants may not predict venlafaxine treatment response in China Han population with major depressive disorder. Psychiatry Res. 2018;270:1179-1180. doi:10.1016/j.psychres.2018.10.038

21. Kavirajan H. Bupropion switch for a depressed patient with venlafaxine-associated night sweats. $J$ Clin Psychopharmacol. 2018;38(5):536-537. doi:10.1097/JCP.0000000000000925

22. Poitras V, Visintini S. Desvenlafaxine versus Venlafaxine for the Treatment of Adult Patients with Major Depressive Disorder: A Review of the Comparative Clinical and Cost-Effectiveness. Ottawa (ON); 2017.

23. Hajhashemi V, Banafshe HR, Minaiyan M, Mesdaghinia A, Abed A. Antinociceptive effects of venlafaxine in a rat model of peripheral neuropathy: role of alpha2-adrenergic receptors. Eur J Pharmacol. 2014;738:230-236. doi:10.1016/j.ejphar.2014.04.046

24. Kwok A, Eggimann GA, Heitz M, Reymond JL, Hollfelder F, Darbre T. Efficient transfection of siRNA by peptide dendrimer-lipid conjugates. Chembiochem. 2016;17(23):2223-2229. doi:10.1002/cbic.201600485

25. Miao X, Fan B, Li R, Zhang S, Lin H; Alzheimer's Disease Neuroimaging Initiative. Network analysis of depression-related transcriptomic profiles. Neuromolecular Med. 2019;21(2):143-149. doi:10.1007/s12017-019-08527-9

26. Yang XH, Song SQ, Xu Y. Resveratrol ameliorates chronic unpredictable mild stress-induced depression-like behavior: involvement of the HPA axis, inflammatory markers, BDNF, and Wnt/beta-catenin pathway in rats. Neuropsychiatr Dis Treat. 2017;13:2727-2736. doi:10.2147/NDT.S150028

27. Yang JW, Ma W, Luo T, et al. BDNF promotes human neural stem cell growth via GSK-3beta-mediated crosstalk with the wnt/beta-catenin signaling pathway. Growth Factors. 2016;34(1-2):19-32. doi:10.3109/08977194.2016.1157791

28. Yang JW, Ru J, Ma W, et al. BDNF promotes the growth of human neurons through crosstalk with the $\mathrm{Wnt} / \beta$-catenin signaling pathway via GSK-3 $\beta$. Neuropeptides. 2015;54:35-46. doi:10.1016/j. npep.2015.08.005 
29. Mostany R, Valdizan EM, Pazos A. A role for nuclear beta-catenin in SNRI antidepressant-induced hippocampal cell proliferation. Neuropharmacology. 2008;55(1):18-26. doi:10.1016/j. neuropharm.2008.04.012

30. Drongitis D, Rainone S, Piscopo M, et al. Epigenetics and cortical spreading depression: changes of DNA methylation level at retrotransposon sequences. Mol Biol Rep. 2016;43(8):755-760. doi:10.1007/s11033-016-4000-4

31. Mukandala G, Tynan R, Lanigan S, O'Connor JJ. The effects of hypoxia and inflammation on synaptic signaling in the CNS. Brain Sci. 2016;6(1):6. doi:10.3390/brainsci6010006

32. Ichikawa T, Nakahata S, Tamura T, Manachai N, Morishita K. The loss of NDRG2 expression improves depressive behavior through increased phosphorylation of GSK3 $\beta$. Cell Signal. 2015;27 (10):2087-2098. doi:10.1016/j.cellsig.2015.07.012

33. Lu H, Li Y, Shu M, et al. Hypoxia-inducible factor-1alpha blocks differentiation of malignant gliomas. FEBS J. 2009;276 (24):7291-7304. doi:10.1111/j.1742-4658.2009.07441.x

34. Tayyab M, Shahi MH, Farheen S, et al. Sonic hedgehog, Wnt, and brain-derived neurotrophic factor cell signaling pathway crosstalk: potential therapy for depression. J Neurosci Res. 2018;96(1):53-62. doi:10.1002/jnr.24104
35. Beier EE, Maher JR, Sheu TJ, et al. Heavy metal lead exposure, osteoporotic-like phenotype in an animal model, and depression of Wnt signaling. Environ Health Perspect. 2013;121(1):97-104. doi:10.1289/ehp.1205374

36. Voleti B, Duman RS. The roles of neurotrophic factor and Wnt signaling in depression. Clin Pharmacol Ther. 2012;91(2):333-338. doi:10.1038/clpt.2011.296

37. Wilkinson MB, Dias C, Magida J, et al. A novel role of the WNT-dishevelled-GSK3beta signaling cascade in the mouse nucleus accumbens in a social defeat model of depression. J Neurosci. 2011;31(25):9084-9092. doi:10.1523/JNEUROSCI.0039-11.2011

38. Inkster B, Nichols TE, Saemann PG, et al. Pathway-based approaches to imaging genetics association studies: Wnt signaling, GSK3beta substrates and major depression. Neuroimage. 2010;53(3):908-917. doi:10.1016/j.neuroimage.2010.02.065

39. Cerpa W, Farias GG, Godoy JA, Fuenzalida M, Bonansco C, Inestrosa NC. Wnt-5a occludes Abeta oligomer-induced depression of glutamatergic transmission in hippocampal neurons. Mol Neurodegener. 2010;5(1):3. doi:10.1186/1750-1326-5-3
Neuropsychiatric Disease and Treatment

\section{Publish your work in this journal}

Neuropsychiatric Disease and Treatment is an international, peerreviewed journal of clinical therapeutics and pharmacology focusing on concise rapid reporting of clinical or pre-clinical studies on a range of neuropsychiatric and neurological disorders. This journal is indexed on PubMed Central, the 'PsycINFO' database and CAS, and is the official journal of The International Neuropsychiatric Association (INA). The manuscript management system is completely online and includes a very quick and fair peer-review system, which is all easy to use. Visit http://www.dovepress.com/testimonials.php to read real quotes from published authors. 